\title{
Collaboration in the Elementary School: What Do Teachers Think?
}

\author{
Mercedes Tichenor ${ }^{1, *} \&$ John Tichenor ${ }^{2}$, \\ ${ }^{1}$ Department of Education, Stetson University, DeLand, Florida, USA \\ ${ }^{2}$ School of Business Administration, Stetson University, DeLand, Florida, USA \\ *Correspondence: Department of Education, 421 N. Woodland Blvd. Unit 8419, Stetson University, DeLand, FL \\ 32723, USA. Tel: 1-386-822-7086. E-mail: mticheno@stetson.edu
}

Received: April 22, $2019 \quad$ Accepted: May 21, 2019 Online Published: May 23, 2019

doi:10.5430/jct.v8n2p54 URL: https://doi.org/10.5430/jct.v8n2p54

\begin{abstract}
Teaching is often seen as an isolated profession in which individual teachers work behind closed doors independently from other teachers. However, this view of teaching as primarily an individual activity belies the reality of modern, collaborative educational practices that most significantly impact student learning. In this study, we examine elementary teachers' perspectives on common collaborative practices and discuss what teachers believe are the biggest benefits of and barriers to teacher collaboration. The results from this investigative survey suggest that although teachers do not regularly participate in many collaborative activities, they believe that collaboration is valuable and an effective use of their time.
\end{abstract}

Keywords: collaboration, perspectives, elementary teachers

\section{Introduction}

Teaching is often seen as an isolated profession in which individual teachers work behind closed doors independently from other teachers. Indeed, according to education historian Jonathan Zimmerman, the architype of a teacher singlehandedly managing and teaching students in a "little red schoolhouse" still has an enormous grasp upon the American historical imagination (Zimmerman, 2009). However, the view of teaching as primarily an individual activity belies the reality of modern, collaborative educational practices that most significantly impact student learning. Rather than student success being primarily a function of individual teachers working with students in their individual classrooms, student achievement is also influenced by teachers' collaborative efforts throughout the school day (Ronfeldt et al., 2015; Goddard et al., 2015).

Research has shown there are higher levels of trust and job satisfaction in schools with greater teacher collaboration (Met Life, 2010). Research has also shown that school environments that support higher-quality collaboration increase the rate of improvement for teachers (Ronfeldt et al., 2015). However, despite the benefits of teacher collaboration, there are still teachers who work in isolation (Dufour, 2004). In fact, the Met Life Survey of the American Teacher reported that teachers, on average, spend only 2.7 hours each week in structured collaboration (Met Life, 2010). The Met Life (2010) study also reported that teachers and principals believe that more collaboration in schools would significantly impact school improvement and student achievement.

There are various definitions of teacher collaboration. Eschler (2016) describes collaboration as involving two or more teachers who work interdependently to share information and knowledge, plan, and problem-solve to achieve a common goal. The Organization for Economic Cooperation and Development (OECD) defines collaboration as teachers working together to improve educational processes and outcomes (OECD, 2009), whereas Vangrieken et al (2015), describe collaboration as joint interactions among individuals to perform shared tasks. Although these definitions may be slightly different in wording, they each view collaboration as encompassing all aspects of the teaching profession. Such collaboration includes many formal and informal activities, such as team teaching, peer observation and coaching, collaborative inquiry and research, team planning, and working on joint activities across classes. According to the 2010 Met Life survey, the most common type of collaborative activity is meeting in teams to discuss how to increase student achievement, while the least common collaboration practice reported is observing and providing feedback to other teachers (Met Life, 2010). More importantly, some research indicates that a school wide 
collaborative culture has positive effects on student achievement when collaborative activities focus on instruction, curriculum, and assessment (Ronfeldt et al., 2015).

A study by the Gates Foundation reported that teachers see professional collaboration as a separate activity, apart from their daily teaching (Bill and Melinda Gates Foundation, 2014). Teachers in the Gates Foundation study recognized the significance of collaboration, but did not see their collaboration practices as ideal; only 7 percent report having strong collaboration models at their schools. However, in a meta-analysis of 82 studies on teacher collaboration, Vangrieken et al (2015) concluded that teacher collaboration is needed to "build schools into learning organizations, to anticipate the growing importance of collaboration in society and to use education as a role model for students to properly prepare them for the future." (p. 17). Harry Wong (2004) maintains that effective schools are places where student achievement is seen as the responsibility of all teachers, not just one classroom teacher. In other words, teacher collaboration is an essential component of effective schools.

In this article, we examine elementary teachers' perspectives on common collaborative practices and discuss what teachers believe are the biggest benefits of and barriers to teacher collaboration. We also provide suggestions on how schools can support a strong collaborative culture among teachers.

\section{Method}

This exploratory study examines the views of teachers on professional collaboration in two public elementary schools. The first elementary school houses approximately 600 students in grades K-5 with about sixty-five percent of students eligible for free or reduced lunch. The population of the second elementary school is a bit larger, housing approximately 900 K-5 students. Roughly seventy-two percent of these students are eligible for free or reduced lunch.

The instrument used in this study consists of closed and open-ended survey items. The closed-ended items ask teachers how often they participate in twenty-six collaborative activities and which of these collaborative activities they believe to be the least and most beneficial. The twenty-six items were selected from commonly recognized teacher collaboration activities and existing surveys on collaboration (e.g., Met Life, 2010, OECD, 2009). The open-ended survey items allow teachers to comment on the benefits of teacher collaboration, barriers to teacher collaboration, and how teacher collaboration can be improved. The surveys were distributed, completed, and collected at a faculty meeting at the end of the school year. Teachers were asked not to identify themselves on the surveys and were given approximately 20 minutes to complete the survey. Participation was completely voluntary; a total of 36 surveys were completed. Tables 1.through 3.present teacher respondents by grade level, highest level of education, and years of experience.

Table 1. Teacher Respondents by Grade Level

\begin{tabular}{lll}
\hline Grade & Count & Percent \\
\hline Primary (K-2) & 18 & $50 \%$ \\
Intermediate (3-5) & 14 & $39 \%$ \\
All (K-5) & 4 & $11 \%$ \\
Total & $\mathbf{3 6}$ & $\mathbf{1 0 0 \%}$ \\
\hline
\end{tabular}

Table 2. Teacher Respondents by Highest Level of Education

\begin{tabular}{lll}
\hline Degree & Count & Percent \\
\hline Bachelor's & 20 & $56 \%$ \\
Master's & 16 & $44 \%$ \\
Total & $\mathbf{3 6}$ & $\mathbf{1 0 0 \%}$ \\
\hline
\end{tabular}

Table 3. Teacher Respondents by Years of Experience

\begin{tabular}{lll}
\hline Years of Experience & Count & Percent \\
\hline Beginning (1-5 years) & 12 & $33 \%$ \\
Experienced (6-10 years) & 5 & $14 \%$ \\
Veteran (11+ years) & 19 & $53 \%$ \\
Total & $\mathbf{3 6}$ & $\mathbf{1 0 0 \%}$ \\
\hline
\end{tabular}




\section{Results}

Table 4. Teacher Responses Regarding Participation in Various Collaborative Activities

\begin{tabular}{|c|c|c|}
\hline $\begin{array}{l}\text { How often did you participate in each collaborative activity } \\
\text { during the past academic year? }\end{array}$ & $\begin{array}{l}\text { Percent of teachers } \\
\text { who responded } \\
\text { "Daily or Weekly" }\end{array}$ & $\begin{array}{l}\text { Percent of teachers } \\
\text { who responded } \\
\text { "Monthly, Rarely, or } \\
\text { Never" }\end{array}$ \\
\hline $\begin{array}{l}\text { Engage in dialogue/professional conversations with your } \\
\text { colleagues on how to improve your teaching }\end{array}$ & 83.3 & 16.7 \\
\hline Participate in joint decision making on grade-level issues & 80.6 & 19.4 \\
\hline $\begin{array}{l}\text { Engage in discussion about the learning development of specific } \\
\text { students }\end{array}$ & 80.6 & 19.4 \\
\hline Plan instruction with grade level team & 77.8 & 22.2 \\
\hline Analyze your teaching practices and outcomes & 72.2 & 27.8 \\
\hline Exchange teaching materials with colleagues & 72.2 & 27.8 \\
\hline Examine and discuss student work & 72.2 & 27.8 \\
\hline Discuss and plan how to help students achieve at higher levels & 69.4 & 30.6 \\
\hline $\begin{array}{l}\text { Discuss and secure new ideas and useful teaching tips from } \\
\text { colleagues }\end{array}$ & 52.8 & 47.2 \\
\hline Discuss and coordinate homework & 41.7 & 58.3 \\
\hline Design tools for assessing student progress & 36.1 & 63.9 \\
\hline $\begin{array}{l}\text { Discuss and decide on the selection of instructional resources and } \\
\text { materials }\end{array}$ & 33.3 & 66.7 \\
\hline Mentor beginning or struggling teachers & 25 & 75 \\
\hline Model specific pedagogical strategies & 22.2 & 77.8 \\
\hline Develop curriculum or some part of the curriculum & 22.2 & 77.8 \\
\hline Teach jointly as a team in the same class (team teach) & 16.7 & 83.3 \\
\hline Participate in joint decision making on school-wide issues & 13.9 & 86.1 \\
\hline $\begin{array}{l}\text { Discuss professional literature with other teachers (books, journal } \\
\text { articles, etc.) }\end{array}$ & 13.9 & 86.1 \\
\hline Work with teachers on extracurricular activity planning & 8.3 & 91.7 \\
\hline $\begin{array}{l}\text { Engage in joint activities across different classes and age groups } \\
\text { (e.g. projects) }\end{array}$ & 5.7 & 94.3 \\
\hline $\begin{array}{l}\text { Engage in collaborative research on a topic of interest to you } \\
\text { professionally }\end{array}$ & 5.6 & 94.4 \\
\hline Observe other teachers' classes and provide feedback & 5.6 & 94.4 \\
\hline Plan instruction across grade-levels & 5.6 & 94.4 \\
\hline $\begin{array}{l}\text { Engage in lesson study with peer teachers (Japanese lesson study } \\
\text { model) }\end{array}$ & 2.9 & 97.1 \\
\hline Take part in professional development that benefits your teaching & 2.8 & 97.2 \\
\hline Plan and lead professional development activities & 2.6 & 97.4 \\
\hline
\end{tabular}

Teachers were asked a series of questions regarding their participation in various collaborative activities during the academic year, ranging from planning instruction with grade level teams to engaging in collaborative research. The response categories included daily, weekly, monthly, rarely, and never. For this exploratory analysis, the response categories were collapsed into two categories: regularly occurring collaborative activities (daily, weekly) and seldom occurring collaborative activities (monthly, rarely, never). Table 4. summarizes the results for all teacher respondents. As illustrated in Table 4., over $75 \%$ of the teachers regularly participated in only four of the twenty-six collaborative activities during the school year. The four activities with over $75 \%$ participation on a regular basis (daily or weekly) include engage in dialogue/professional conversation with your colleagues on how to improve your teaching, plan instruction of grade level team, participate in joint decision making on grade-level issues, and engage in discussion about the learning development of specific students. Of these four activities, the collaborative activity with the largest 
percent of regular participation (83.3\%) was engage in dialogue/professional conversation with your colleagues on how to improve your teaching. On the other hand, less than $25 \%$ of the teachers reported regularly participating in 14 of the 26 listed activities, with the smallest percent of regular participation in the following areas: engage in joint activities across different classes and age groups (5.7\%), plan instruction across grade levels (5.6\%), observe other teachers' classes and provide feedback (5.6\%), engage in collaborative research on a topic of interest to you professionally (5.6\%), engage in lesson study with peer teachers $(2.9 \%)$, take part in professional development that benefits your teaching (2.8\%), and plan and lead professional development activities (2.6\%). In each of these areas, less than six percent of the teachers reported regular participation.

Table 5. Teacher Responses on How Beneficial Each Collaborative Activity Is

\begin{tabular}{|c|c|c|}
\hline How beneficial is this collaborative activity? & $\begin{array}{l}\text { Percent of teachers } \\
\text { who responded "Very } \\
\text { or Somewhat } \\
\text { Beneficial" }\end{array}$ & $\begin{array}{l}\text { Percent of teachers } \\
\text { who responded } \\
\text { "A Little or Not At All } \\
\text { Beneficial" }\end{array}$ \\
\hline Analyze your teaching practices and outcomes & 100 & 0 \\
\hline $\begin{array}{l}\text { Discuss and secure new ideas and useful teaching tips from } \\
\text { colleagues }\end{array}$ & 100 & 0 \\
\hline Examine and discuss student work & 100 & 0 \\
\hline $\begin{array}{l}\text { Discuss and plan how to help students achieve at higher } \\
\text { levels }\end{array}$ & 100 & 0 \\
\hline Exchange teaching materials with colleagues & 97.2 & 2.8 \\
\hline $\begin{array}{l}\text { Engage in discussion about the learning development of } \\
\text { specific students }\end{array}$ & 97.2 & 2.8 \\
\hline $\begin{array}{l}\text { Take part in professional development that benefits your } \\
\text { teaching }\end{array}$ & 97.2 & 2.8 \\
\hline Mentor beginning or struggling teachers & 97.1 & 2.9 \\
\hline $\begin{array}{l}\text { Engage in dialogue/professional conversations with your } \\
\text { colleagues on how to improve your teaching }\end{array}$ & 94.4 & 5.6 \\
\hline Participate in joint decision making on grade-level issues & 94.4 & 5.6 \\
\hline Design tools for assessing student progress & 88.9 & 11.1 \\
\hline Plan instruction with grade level team & 88.8 & 11.2 \\
\hline Participate in joint decision making on school-wide issues & 86.1 & 13.9 \\
\hline Observe other teachers' classes and provide feedback & 85.7 & 14.3 \\
\hline Model specific pedagogical strategies & 85.7 & 14.3 \\
\hline $\begin{array}{l}\text { Discuss and decide on the selection of instructional resources } \\
\text { and materials }\end{array}$ & 82.9 & 17.1 \\
\hline $\begin{array}{l}\text { Discuss professional literature with other teachers (books, } \\
\text { journal articles, etc.) }\end{array}$ & 80.6 & 19.4 \\
\hline Develop curriculum or some part of the curriculum & 80 & 20 \\
\hline $\begin{array}{l}\text { Engage in collaborative research on a topic of interest to you } \\
\text { professionally }\end{array}$ & 74.3 & 25.7 \\
\hline Work with teachers on extracurricular activity planning & 71.4 & 28.6 \\
\hline Teach jointly as a team in the same class (team teach) & 70.6 & 29.4 \\
\hline Plan instruction across grade-levels & 68.6 & 31.4 \\
\hline Discuss and coordinate homework & 63.9 & 36.1 \\
\hline $\begin{array}{l}\text { Engage in joint activities across different classes and age } \\
\text { groups (e.g. projects) }\end{array}$ & 61.8 & 38.2 \\
\hline Plan and lead professional development activities & 54.3 & 45.7 \\
\hline $\begin{array}{l}\text { Engage in lesson study with peer teachers (Japanese lesson } \\
\text { study model) }\end{array}$ & 53.1 & 46.9 \\
\hline
\end{tabular}


Table 5 presents the results of teacher responses to the question, "How beneficial is this collaborative activity." As illustrated in Table 5 over $75 \%$ of the teachers reported that 18 of the 26 activities are very or somewhat beneficial. Of those 18 activities, over $90 \%$ of the teachers reported 10 activities as being very or somewhat beneficial, while $100 \%$ of teachers identified four activities as being very or somewhat beneficial. The four activities that $100 \%$ of the teachers reported as very or somewhat beneficial include analyze your teaching practices and outcomes, discuss and secure new ideas and useful teaching tips from colleagues, examine and discuss student work, and discuss and plan how to help students achieve at higher levels. It is interesting to note that although $100 \%$ of the teachers believe these are valuable collaborative activities, less than $75 \%$ of the teachers reported participating in them, with approximately $50 \%$ of the teachers reported participation in discuss and secure new ideas and useful teaching tips from colleagues. The two activities reported as very or somewhat beneficial by the fewest teachers were engage in lesson study with peer teachers (53.1\%) and plan and lead professional development activities (54.3\%). In each of these two areas, approximately half of the teachers reported these activities as very or somewhat beneficial. Overall, teachers found the collaborative activities listed on the survey to be worthwhile and beneficial.

Table 6. Collaborative Activities with the Greatest "Mismatch" between Teachers' Perceived Benefit and Teachers' Regular Participation

\begin{tabular}{|c|c|c|c|}
\hline & $\begin{array}{l}\text { Percent of } \\
\text { teachers who } \\
\text { responded "Very } \\
\text { or Somewhat" } \\
\text { to how beneficial } \\
\text { the collaborative } \\
\text { activity is }\end{array}$ & $\begin{array}{l}\text { Percent of } \\
\text { teachers who } \\
\text { responded "Daily } \\
\text { or Weekly" to } \\
\text { participating in } \\
\text { collaborative } \\
\text { activity }\end{array}$ & $\begin{array}{l}\text { Difference } \\
\text { between percent } \\
\text { who reported } \\
\text { activity was } \\
\text { beneficial and } \\
\text { percent who } \\
\text { regularly } \\
\text { participate in } \\
\text { activity }\end{array}$ \\
\hline $\begin{array}{l}\text { Take part in professional development that } \\
\text { benefits your teaching }\end{array}$ & 97.2 & 2.8 & 94.4 \\
\hline Mentor beginning or struggling teachers & 97.1 & 25.0 & 72.1 \\
\hline $\begin{array}{l}\text { Participate in joint decision making on } \\
\text { school-wide issues }\end{array}$ & 86.1 & 13.9 & 72.2 \\
\hline $\begin{array}{l}\text { Observe other teachers' classes and provide } \\
\text { feedback }\end{array}$ & 85.7 & 5.6 & 80.1 \\
\hline Model specific pedagogical strategies & 85.7 & 22.2 & 63.5 \\
\hline $\begin{array}{l}\text { Discuss professional literature with other } \\
\text { teachers (books, journal articles, etc.) }\end{array}$ & 80.6 & 13.9 & 66.7 \\
\hline $\begin{array}{l}\text { Develop curriculum or some part of the } \\
\text { curriculum }\end{array}$ & 80.0 & 22.2 & 57.8 \\
\hline $\begin{array}{l}\text { Engage in collaborative research on a topic of } \\
\text { interest to you professionally }\end{array}$ & 74.3 & 5.6 & 68.7 \\
\hline $\begin{array}{l}\text { Work with teachers on extracurricular activity } \\
\text { planning }\end{array}$ & 71.4 & 8.3 & 63.1 \\
\hline $\begin{array}{l}\text { Teach jointly as a team in the same class (team } \\
\text { teach) }\end{array}$ & 70.6 & 16.7 & 53.9 \\
\hline Plan instruction across grade-levels & 68.6 & 5.6 & 63.0 \\
\hline $\begin{array}{l}\text { Engage in joint activities across different } \\
\text { classes and age groups (e.g. projects) }\end{array}$ & 61.8 & 5.7 & 56.1 \\
\hline $\begin{array}{l}\text { Plan and lead professional development } \\
\text { activities }\end{array}$ & 54.3 & 2.6 & 51.7 \\
\hline $\begin{array}{l}\text { Engage in lesson study with peer teachers } \\
\text { (Japanese lesson study model) }\end{array}$ & 53.1 & 2.9 & 50.2 \\
\hline
\end{tabular}


Next, we examine the collaborative activities teachers believe are most beneficial, but also report participating the least on a regular basis. Table 6. presents 14 collaborative activities with the greatest "mismatch" between what teachers think are most beneficial yet report regularly participating in the least. For example, teachers overwhelmingly agreed (97.1\%) that mentoring beginning or struggling teachers is an important activity, yet only 25 percent of the respondents reported regularly (daily or weekly) participating in such collaborative activities. For each of the 14 collaborative activities listed in Table $8 ., 25 \%$ or less of the teachers reported regularly participating in during the past academic year, while at least $50 \%$ of the teachers reported each of the activities being beneficial. The biggest difference between believed benefits and actual participation are: take part in professional development that benefits your teaching, observe other teachers' classes and provide feedback, participate in joint decision making on school-wide issues, and mentor beginning or struggling teachers. Each of these collaborative activities had a difference score of $72 \%$ of higher. Difference scores were calculated by subtracting the percent of teachers' responses to participating in the collaborative activity from the percent of teachers' responses to how beneficial the activity is (perceived value). Although this is only an exploratory study of what a small group of teachers think about the importance of collaborative activities with other teachers, a rudimentary analysis may identify areas for school administrators to target for increased teacher collaboration. For example, the results may indicate that administrators should provide more opportunities for teachers to more regularly observe other teachers' classes and provide feedback.

\subsection{Teacher Responses to Open-Ended Questions}

In addition to the closed-ended survey items, four open-ended items were asked to examine teachers' thoughts about their collaborative experiences. The first open-ended item was What do you think is the most important benefit of teacher collaboration? The most frequent responses related to how collaboration allows teachers to share ideas and viewpoints, provides teachers with new and fresh perspectives, and allows teachers to learn from each other. In response to this question, one teacher wrote, "Experienced teachers can model for less experienced teachers. As well, less experienced teachers can help older teachers with new ideas." From the variety of responses, it seems clear that most teachers in this study see value in teacher collaboration; most comments alluded to the benefit of learning from the practices of other teachers and many specifically linked the practices to improved student learning.

The next open-ended question was What do you think is the biggest barrier to teacher collaboration? The most common response from teachers related to a lack of time and opportunity to collaborate with other educators; 74 percent of the respondents mentioned time as a barrier to collaboration. Further, teachers included comments about trust, willingness, attitude, and insecurity toward collaborative activities as barriers for teachers. For example, one teacher wrote, "collaboration is never built into our schedules" and another commented that "misunderstandings and miscommunications about goals" were the biggest barriers.

The third open-ended question was What collaborative activities would you want to increase? Most of the responses to this item related to activities that support instructional practices, such a s lesson planning, observations of teaching by peers, and analyzing student work. The final open-ended question was What suggestions do you have that would improve teacher collaboration? Many responses related to building in time and opportunities during the school day to collaborate with other teachers. One teacher commented that "collaboration should be made a priority." A few comments reflected issues such as team building and making collaboration a pleasant experience. Overall, teachers seemed to want more structured opportunities to collaborate with other educators.

\section{Conclusion and Recommendations for Future Research}

The results from this exploratory survey suggest that teachers do not regularly participate in many collaborative activities. One teacher even commented, "In my 3 year career in a public school, my grade level has never worked together collaboratively." While this single comment may be an outlier (perhaps there was at least a minimal level of collaboration even for this teacher), the results from this study indicate that levels of collaboration are low in many areas. Nevertheless, teachers in this exploratory study believe that most collaborative activities are beneficial and an effective use of their time. Further, even though the participation levels are low, teachers reported participating in a variety of collaborative activities, mostly focusing on improved teaching, planning within grade level, and academic growth of students. Collaborative activities that teachers in this study do not commonly participate include planning across grade levels, peer observations, collaborative action research, professional development, and discussing professional literature. However, the teachers in this study believe that such collaboration is valuable and an effective use of time. 
The teachers in this study overwhelmingly responded that lack of time was the single largest barrier to greater teacher collaboration. Teachers believe time and opportunity are the biggest barriers and would like to see more opportunities to collaborate be part of the school day. This finding mirrors previous studies documenting that teachers have limited opportunities for collaborative activities (Bill and Melinda Gates Foundation, 2014; Met Life, 2010). The Gates Foundation specifically concluded that teachers need more time to develop and foster meaningful collaborative practices (Bill and Melinda Gates Foundation, 2014).

However, simply providing more time in the school day for collaboration is not enough. As indicated in some of the teachers' comments, teachers need to know how to collaborate. The idea that individuals who collaborate must go through stages of development has been well-developed in team and leadership research literature. For example, Bruce Tuckman's classic Team Development Model states that all productive teams go through four stages: forming, storming, norming, and performing (Tuckman, 1965). The point is that school administrators should provide more than additional time for teachers to collaborate; they should also provide supportive professional development activities and clear communication about purpose, goals, and expected outcomes of collaboration. Finally, for collaboration to be beneficial, collaborative endeavors must be strong and of high-quality. In other words, professional collaboration is more than simply getting teachers together; collaboration should be deliberative and meaningful in order to notably benefit teachers and students. Collaboration must be made a priority by school districts and administrators (Tichenor \& Tichenor, 2018).

A major limitation of this research is that it only utilized a convenience sample of teachers from two schools. Future research should incorporate teachers from multiple schools who engage in high quality collaborative activities. However, a particular challenge with larger scale research is variations in the way collaboration is defined (Vangrieken et al., 2015). One way to help with the definitional challenge of collaboration is for future research to incorporate qualitative models such as focus group interviews with teachers. Using qualitative methods, more refined definitions of collaboration may be developed that would allow researchers to distinguish among different types of high-quality collaboration. With more refined definitions of collaboration, a "Collaboration Index" may be developed that allows collaborative practices to be compared across schools. In other words, do some schools demonstrate higher levels of collaboration than others? If so, are specific collaborative activities related to higher levels of student achievement at the schools? These will be difficult questions to answer, but we believe it is important to continue to question the assumption of teaching being primarily done by individual teachers.

\section{References}

Bill \& Melinda Gates Foundation (2014). Teachers know best: Teachers' views on professional development. Seattle, WA: Author.

Dufour, R. (2004). What is a professional learning community? Educational Leadership, 61(8), 6-11.

Eschler, B. (2016). Finnish teacher collaboration: The behaviors, learning, and formality of teacher collaboration (Doctoral dissertation). Retrieved from All Theses and Dissertations. (6191)

Goddard, R., Goddard, Y., Eun Sook, K., \& Miller, R. (2015). A theoretical and empirical analysis of the roles of instructional leadership, teacher collaboration, and collective efficacy beliefs in support of student learning. American Journal of Education, 121(4), 501-530. https://doi.org/10.1086/681925

Met Life (2010). Met Life survey of the American teacher: Collaborating for student success. New York, Author. https://doi.org/10.1787/9789264068780-sum-pt

Organisation for Economic Cooperation and Development (2009). Creating effective teaching and learning environments? First results from TALIS. Paris, France: Author.

Ronfeldt, M., Farmer, S., McQueen, K., \& Grissom, J. (2015). Teacher collaboration in instructional teams and student achievement. American Educational Research Journal, 52(3), 475-514. https://doi.org/10.3102/0002831215585562

Tichenor, M., \& Tichenor, J. (2018). The many sides of teacher collaboration. Kappa Delta Pi Record, 53(3), 139-142. https://doi.org/10.1080/00228958.2018.1481663

Tuckman, B. W. (1965). Developmental Sequence in Small Groups. Psychological Bulletin, 63(6), 384-399. https://doi.org/10.1037/h0022100

Vangrieken, K., Dochy, F., Raes, E., \& Kyndt, E. (2015). Teacher collaboration: A systematic review. Educational 
Research Review, 15, 17-40. https://doi.org/10.1016/j.edurev.2015.04.002

Wong, H. (2004). Collaborating with Colleagues to Improve Student Learning. ENC Focus, 11(6). Retrieved from www.NewTeacher.com

Zimmerman, J. (2009). Small wonder: The little red schoolhouse in history and memory. New Haven: Yale University Press. 